\title{
The Influence of Tacit Knowledge and Intellectual Capital towards Innovation
}

\author{
Augustina Asih Rumanti, Amelia Kurniawati, Hendru, and Ceicalia Tesavrita
}

\begin{abstract}
Innovation in an organization is importance, because it is the key to compete in this globalization era. Especially for small and medium enterprises that need to compete with large companies. There are some views that if the model management of knowledge (tacit knowledge) is good then it will affect the innovation of an organization. In addition to manage the management of knowledge, wealth (intellectual capital) of an organization that is invisible is also an important factor for innovation of the organization. This research is done to find out the influence of the management of knowledge and intellectual capital of an organization towards innovation of an SME. This research is conducted to analyze the effect by using the results of the questionnaire and then processed using SEM software Partial Least Square (PLS).

The result of data processing based on the result of the PLS software shows that tacit knowledge does not affect the innovation, due to the lack of attention from SME Karya Kulit to develop knowledge of each employee that resulted in difficulties to give ideas or innovation. Result for Intellectual Capital which affect the innovation can happen because the owners of SME have unknowingly implemented or considered factors of Intellectual Capital at every process in SME.
\end{abstract}

Index Terms-Tacit knowledge, intellectual capital, innovation.

\section{INTRODUCTION}

In the era of globalization it is almost impossible to find a company or any organization that is not related to or not requiring an innovation. This is because of in the era of globalization, competition among companies or organizations is tight, because each company can easily produce same product. The development of business environment in the era of globalization is demanding any company, both large companies medium, and a small company to have innovation.

One of resources or input of innovation is by making use of knowledge from the organization. Knowledge of the organization is divided into two namely explicit knowledge and tacit knowledge. Explicit knowledge is knowledge that has been documented, easily modified and is articulated as well as objective, while tacit knowledge is knowledge that has not been documented and is attached in the one, not easily to be revealed and tend to subjective. Another factor which

Manuscript received September 12, 2016; revised December 23, 2016. Augustina Asih Rumanti and Amelia Kurniawati are with the Department of Industrial Engineering, Telkom University, Indonesia (e-mail: augustinaar@gmail.com, ameliakurniawati@telkomuniversity.ac.id).

Hendru is with the Department of Industrial Engineering, Atma Jaya Catholic University, Indonesia (e-mail: hendru23@gmail.com).

Ceicalia Tesravita is with the Department of Industrial Engineering, Parahyangan Catholic Universtity, Indonesia (e-mail: ceicalia.tesa@gmail.com). could affect innovation is intellectual capital which is intangible asset and wealth that can be categorized as human capital, relational capital, and structural capital.

Based on several previous researchs, it is known that there are relation among tacit knowledge, intellectual capital, and innovation. Because of that, this research will show the influence of tacit knowledge and intellectual capital towards innovation in SMEs Karya Kulit, which is SMEs with skin handicraft that needs a new breakthrough to survive competition with big companies.

Formulation of the problem of this research is to analyze the influence of tacit knowledge and intellectual capital towards innovation. The purposes of this research are:

1) Identify the influence of tacit knowledge and intellectual capital towards innovation.

2) Analyze the influence between of tacit knowledge and intellectual capital towards innovation based on results.

\section{LITERATURE REVIEW}

\section{A. Tacit Knowledge}

There are so many definitions of tacit knowledge, but Polanyi (1969) well known as the founder of the concept of tacit knowledge. Polanyi simplifies all the essence of tacit knowledge in a sentence "we know more than we can tell" and easy explanation like ability to realize the face of someone, ski or ride a bicycle, it is difficult to explain how that can be done [1].

All the research on the tacit knowledge followed by explain tacit knowledge as knowledge about the techniques, the method, and designs on the work in some way and some consequences, even when no one can explain why. Nonaka (1991) explain further tacit knowledge that is very personal and hard to become a well formulated, and hence difficult to be communicated to others, and further explained there are two dimensions of the tacit knowledge that the first is the technical dimension is more often called know-how, the second dimension is cognitive dimension containing trust, the idea, and the value that we often choose [1].

\section{B. Intellectual Capital}

Some researchers revealed the definition of intellectual capital as follows [2]:

1) Intellectual Capital is elusive, but once discovered and exploited will provide a new source base organization to compete and win (Bontis, 1996).

2) Intellectual Capital is the term given to combining intangible assets from the market, intellectual property, infrastructure and human center can make a company 
function (Brookings, 1996).

3) The Intellectual Capital is intellectual material (knowledge, information, intellectual property, experience) that can be used to create wealth. It is a force to be collective or a set of useful knowledge (Stewart, 1997).

4) Intellectual Capital is the effective use of knowledge work (finished product) as the position of the information (raw materials) Bontis (1998).

5) Intellectual Capital is considered as an element of the market value of the company and also the premium market (Oleve, Roy and Wenter, 1999).

6) Many practitioners who stated that intellectual capital consists of three main elements (Stewart, 1998, Sveiby, 1997, Saint-Onge, 1996, Bontis 2000) namely: Human Capital, Structural Capital, Relational Capital.

Many practitioners who stated that intellectual capital consists of three main elements (Stewart, 1998, Sveiby, 1997, Saint-Onge, 1996, Bontis 2000), namely: Human Capital, Structural Capital, Relational Capital [2].

\section{Innovation}

The concept of innovation have a long history and different understanding, especially based on competition between companies and a different strategy that can be used to compete. Schumpeter often regarded as the first economic experts who give attention to the importance of an innovation. Schumpeter (1949) said that innovation consists of five elements i.e. 1). the introduce a qualitative change in new product or existing products , 2). the industry to introduce new process , 3). the open new markets , 4). developed new supply source on raw materials or other inputs, and 5). changes in industrial organization. [3]

Innovation is crucial in the success and competitiveness of companies .Innovation seen building blocks of matter into a competitive advantage [4]. Hill \& Jones (1998) said that successful innovation of a company products or services will provide something unique which will make a competitor reduced [4]

According Hauschildt in 1993, innovation can be divided into several dimensions [5]:

\section{1) Content dimension}

In this case, innovation differentiated depending on how problem happened. Is the problem solved in new ways, whether by using existing tools, whether by using the new tools, or by using traditional tools, but in a more efficient and more effective.

\section{2) Subjectivity dimension}

Subjectivity dimension here means the attention or curiosity to technological changes is the key to innovation.

\section{3) Process dimension}

Process Dimension very clearly defined where the innovation begins and ends. According to Utterback in 1971, the process of innovation is not a linear process, but is a parallel process that consists of several iterations

\section{Partial Least Square (PLS)}

Wold in 1985, states that the Partial Least Square (PLS) is a powerful analytical method because it is not based on many assumptions. Data should not normal multivariate distribution (with a scale indicator category to the ratio can be used on the same model), the sample size should not be large and residual distribution [6].

Steps PLS-based structural equation modeling is as follows [7]:

1) Designing structural models (inner model)

2) Designing a measurement model (outer model)

3) Constructing the path diagram

4) Convert the path diagram in the system of equations

5) Parameter Estimation

6) Evaluation of goodness of fit

7) Testing Hypothesis (resampling bootstrapping)

\section{RESEARCH METHODOLOGY}

In Fig. 1 is shown in the research methodology of this study, which is divided into six parts:

\section{A. Research Preparation}

Preparation of research is the earliest stage of research in outline at this stage is how to step by step to determine the topics to be observed, can be based on the existing problems in Small Units Medium Enterprises (SMEs) or based on the literature obtained

\section{B. Literature Review}

The stage that provides information and all theory that support for this study.

\section{Research Design}

This stage is making hypothesis and research model until we make all the variables that used in this research.

\section{Collection and Processing Data}

This stage researcher will conduct data collection using interviews and surveys, with a questionnaire to the owners and workers of SMEs Karya Kulit so that the data obtained is primary data. The questionnaire will be distributed to the owners and all employees of SMEs Karya Kulit

\section{E. Analysis and Discussion}

The next stage after its done processing the data, there is analysis and discussion of the results of data processing. At this stage of the analysis is divided into two parts: first analysis of the results of the software PLS then analyzes the research model

\section{F. Conclusions and Suggestions}

After getting the analysis of the data processing, the researcher can draw overall conclusions of the study that will prove whether the research objectives are fulfill or not, and also will give a conclusion whether tacit knowledge and intellectual capital will affect innovation. Suggestions are input to SMEs Karya Kulit and also for similar studies in the future.

Tacit Knowledge variables have some indicators that obtained from previous study [8]. The variables are experience, personal interaction, community, situation, condition, transfer knowledge, target oriented, and informal. For Intellectual Capital there are three indicators of 
intellectual capital in the form of three main elements of intellectual capital is human capital, strucrtural capital, and relational capital according to Stewart (1998), Sveiby (1997), Saint-Onge (1996), Bontis (2000) [2]. For Innovation, the variables come from previous study there are research, strategy, knowledge, experience and uniqueness [9]. The hypothesis for this research is shown at Fig. 2, for the first hypothesis is between tacit knowledge towards innovation and the second hypothesis is intellectual capital towards innovation.
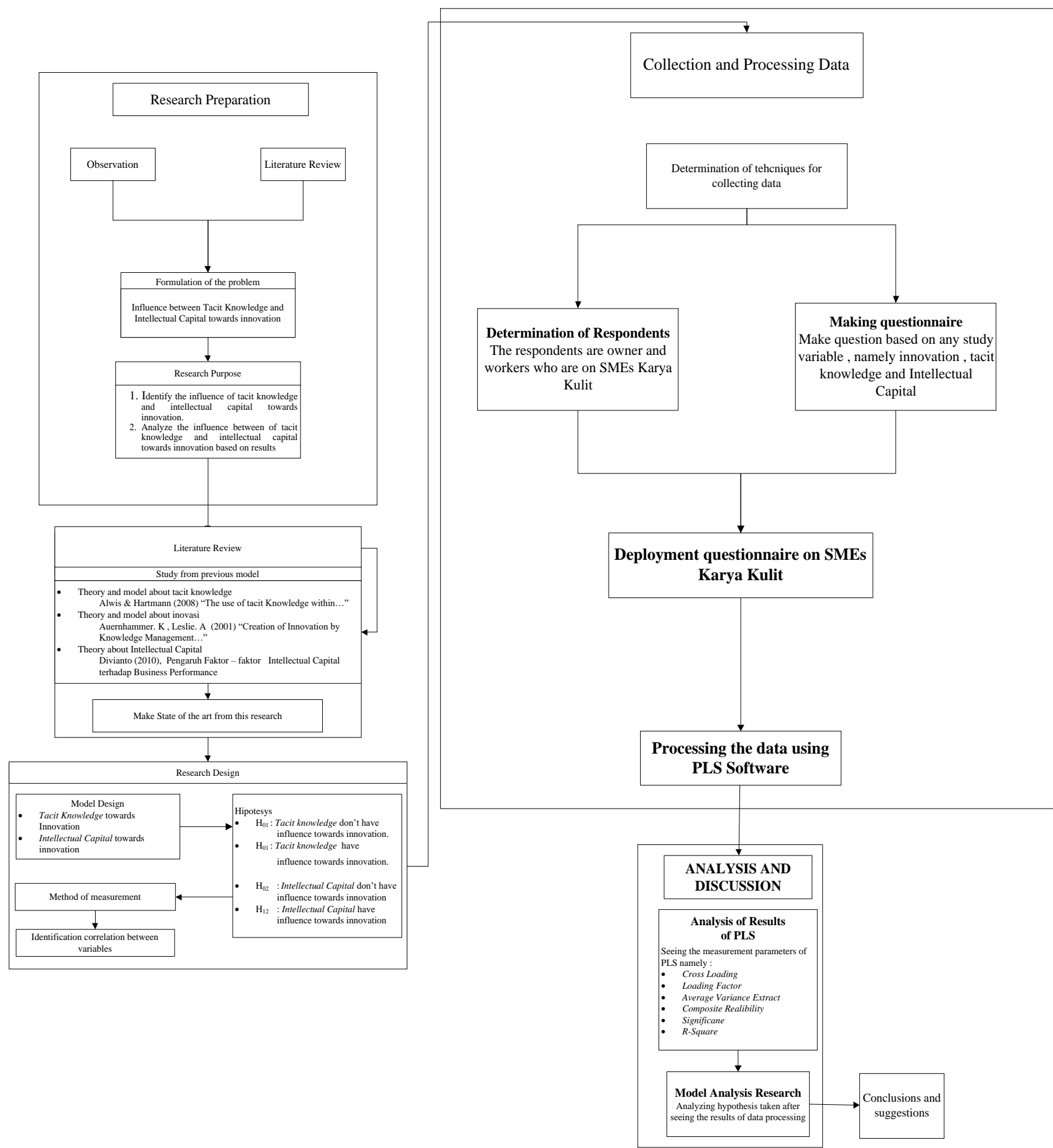

Fig. 1. Research methodology.

\section{ANALYSIS}

\section{A. Measurement Validation Analysis}

Validation of the measuring instrument uses two parameters: the value of the loading factor and cross loading. An indicator as valid if it has a loading factor value above 0.5 but in this study the initial calculation, there are several indicators that have a factor loading values below 0.5 . The indicators that have a factor loading values below 0.5 are considered not appropriate to measure latent variables so that this indicator be discarded and re-calculation. After revising II it can be seen that all the indicators already have a factor loading values above 0.5 .

Next validation measuring instrument can be seen from the cross loading where the value of cross loading an indicator should be higher than the value of cross loading other indicators in order to be valid. Differences of cross loading 
the loading factor is the value of cross loading shows a comparison of an indicator to measure the construct than used to measure other constructs. From the data processing is known, there are several indicators that have a value in a variable cross loading its manifestation is smaller when compared with the value of the other manifest variables indicators that have value in the variable cross loading its manifestation is smaller when compared with the value of the other manifest variables omitted as not precisely measure its manifestation variables and should be re-calculation, but because of there are several variables manifest that gone if we do the re-calculation and can change the whole model, so in this research just want to do fitting model and didn't do the re-calculation.

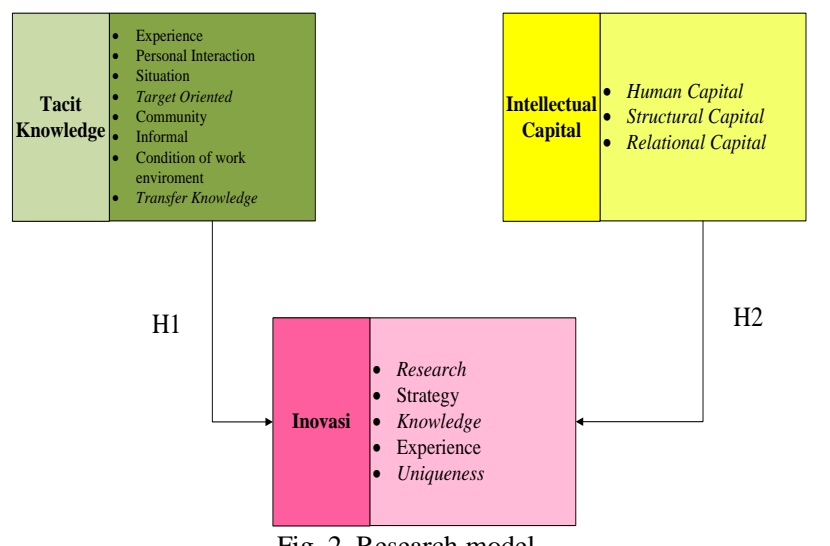

Fig. 2. Research model.

There are many indicators used to measure variables invalid manifest this can be caused by items of statements made to an indicator variable cannot explain its manifestation and can also be caused by people who responded to the questionnaire do not understand the purpose of the statements contained in the indicator so that one of the interpret the statement.

\section{B. Reliability Analysis of Research Variables}

The reliability of this research seen from the AVE (Average Variance Extracted) and CR (Composite Reliability) of output data processed using software Smart PLS 2. A said to be reliable if the variable has a value above $0.5 \mathrm{AVE}$ and CR values above 0.7 . In this study the value AVE and CR there are several values below 0.5 (for the AVE) and below 0.7 (for CR) so that it can be said of all the variables used in this study has not been reliable and has good reliability, this is because of at the stage of validation, there are several indicators that didn't pass for factor loading and cross loading and that make the indicator not reliable and valid.

\section{Result from PLS Computation}

The level of Significant can be identified from the value of the T-statistic. Significant can be met if the value of the $\mathrm{T}$-statistic greater than 3,182. Values obtained from table $\mathrm{T}$ distribution with the use of an alpha of 0.05 and the number of respondents is 4 people, so that the table $\mathrm{T}$ distribution must be alpha 0.05 with $v=n-1=4-1=3$. Here is the value result from all variables manifest that used for analyze in this research there are mean, AVE, CR, T-stat and significance to independent variable.

TABLE I: RESULT FROM PLS

\begin{tabular}{|c|c|c|c|c|c|}
\hline $\begin{array}{c}\text { Dependent } \\
\text { Variable }\end{array}$ & $\begin{array}{l}\text { Independent } \\
\text { Variable }\end{array}$ & AVE & $\mathrm{CR}$ & T-Stat & Sig \\
\hline \multirow{8}{*}{ 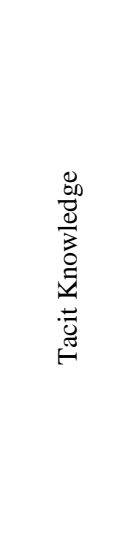 } & Experience & 0.44 & 0.42 & 5.69 & $v$ \\
\hline & Personal Interaction & 0.72 & 0.88 & 3.64 & v \\
\hline & Community & 0.55 & 0.78 & 3.45 & v \\
\hline & Situation & 0.36 & 0.4 & 1.78 & $x$ \\
\hline & Condition & 0.72 & 0.88 & 1.08 & $x$ \\
\hline & Transfer Knowledge & 0.65 & 0.06 & 0.26 & $x$ \\
\hline & Target Oriented & 0.73 & 0.23 & 0.04 & $x$ \\
\hline & Informal & 0.91 & 0.97 & 2.38 & $x$ \\
\hline \multirow{3}{*}{ 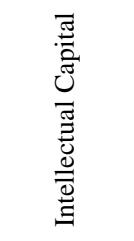 } & Human Capital & 0.5 & 0.6 & 0.32 & $x$ \\
\hline & Structural Capital & 0.39 & 0.21 & 5.1 & $v$ \\
\hline & Relational Capital & 0.27 & 0.15 & 4.53 & $v$ \\
\hline \multirow{5}{*}{ 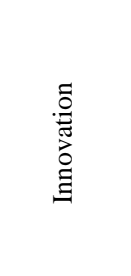 } & Strategy & 0.56 & 0.01 & 3.56 & $v$ \\
\hline & Research & 0.67 & 0.79 & 3.04 & $x$ \\
\hline & Uniqueness & 0.33 & 0.43 & 0.35 & $x$ \\
\hline & Experience & 0.74 & 0.67 & 11.27 & $v$ \\
\hline & Knowledge & 0.81 & 0.75 & 0.74 & $x$ \\
\hline
\end{tabular}


From Table I it can be seen that the factors that have a significant impact on tacit knowledge is just experience, personal interaction and community. For Intellectual Capital there are Structural Capital and Relational Capital. Innovation just strategy and experience

In the latent variable of Tacit knowledge manifest there are five variables that do not have significant influence are Situation, Condition, Transfer Knowledge. For intellectual capital there is one variable that do not have significant influence is Human Capital. Innovation has three variables there are research, uniqueness and knowledge. Seeing variables that do not have significant influence, SMEs Karya Kulit must be considered this factor.

\section{Variability Analysis of Research Model}

Variability research model can be seen from the R-square value. R-Square value can be seen in Table II below.

\begin{tabular}{|c|c|}
\hline \multicolumn{2}{|c|}{ TABLE II: R-SQUARE VALUE } \\
\hline Dependent Variable & $R$ - Square \\
\hline Intellectual Capital & 1 \\
\hline Tacit Knowledge & 0.459068 \\
\hline Innovation & 0.294569 \\
\hline
\end{tabular}

R-square values of the Tacit Knowledge is at 0,4591 which means the variance that can be explained by its manifestation variable is equal to $45,91 \%$ and $54,09 \%$ is explained by other factors and to the R-square for Tacit knowledge is moderate while the R-square value of intellectual capital 1 which shall mean variance that can be explained by its manifestation variable is equal to $100 \%$ and R-square for intellectual capital is strong.

\section{E. Research Hypothesis Analysis}

Result testing the hypothesis of this research, can be seen from the value of t-statistic resulting from the path on the coefficient of. A limit for this research is worth $\pm 3,182$ with the value of $\mathrm{v}=3$ and $\alpha / 2=0,0025$, if the value in range \pm 3,182 , will result accept $\mathrm{H}_{0}$ received and rejected $\mathrm{H}_{1}$, but if above $\pm 3,182$ will result accept $\mathrm{H}_{1}$ and $\mathrm{H}_{0}$ rejected.

This research has two main hypotheses, first the influence of tacit knowledge between tacit knowledge into innovation and intellectual capital towards innovation (H2).The complete statement from the following is a hypothesis that there is a whole in this research:

3) $\mathrm{H}_{01}$ : Tacit knowledge don't have influence towards Innovation.

$\mathrm{H}_{11}$ : Tacit knowledge have influence towards innovation.

4) $\mathrm{H}_{02}$ : Intellectual Capital don't have influence towards innovation

$\mathrm{H}_{12}$ : Intellectual Capital have influence towards Innovation

The result from this research is shown in Table III.

TABLE III: HYPOTHESIS RESULTS

\begin{tabular}{|c|c|l|}
\hline Dependent Variable & T-statistics & Result \\
\hline Tacit Knowledge $\rightarrow$ Innovation & 2,48389 & Accept $\mathrm{H}_{01}$ \\
\hline Intellectual Capital $\longrightarrow$ Innovation & 3,87747 & Accept $\mathrm{H}_{12}$ \\
\hline
\end{tabular}

The result for hypothesis is tacit knowledge doesn't have influence towards innovation. This is contradiction to the previous study that shown tacit knowledge has influence towards innovation [8].

Some of the intellectual capital factor is affect innovation like Human Capital and Structural Capital can be the source for innovation. Based on that statement, the result from this research is showing that intellectual Capital has influence towards innovation [10].

\section{F. Influence Analysis of Tacit Knowledge and Intellectual Capital towards Innovation}

On this research produce a conclusion that does not happen the influence between tacit knowledge to innovation, this can be seen from the workers SMEs the work of the skin is still not able to do changes or give innovation based on the experience or the knowledge is in themselves, whereas workers from SMEs Karya Kulit is already having considerable experience old in the field of skin handicraft. The innovation is rarely comes out from worker because of lack it is still lacking the intention of the workers to express the idea for SME, and they don't have desire to find the source from external source about the skin handicraft, so resulting the worker's knowledge about market condition will become less.

According to its calculations of PLS software shows that the source of tacit knowledge has the significant effect are experience, personal interaction , and the community .It was because SME Karya Kulit most workers from SMEs are the family of the owner or has been working from generation to generation, that could be the most impact on tacit knowledge of SME Karya Kulit .Five other sources like a, the condition, the transfer of knowledge, oriented and informal the target did not influence significantly this can be because of several factors this:

1) The craft was not all in one place, sometimes taken home by several workers.

2) The workers have no individual target, just follows owner's target

3) Employees don't want to say their aspiration and idea, and also the employees don't want to seek information from external source.

On the research indicated that the occurrence of influence between intellectual capital to innovation, and unconsciously intellectual capital SMEs Karya Kulit been carried out by each worker and also especially for the owner. In terms of human capital, can be seen that the ability and intelligence of each employees to said to be high for making the handicraft, but less motivation to using their ability for making SME Karya Kulit to become different from other SMEs in terms of innovate. Relational capital to SME Karya Kulit contributes quite wide for the small and medium enterprises to innovate. There can be seen with his business of smes has been leading to the ,market orientation and already give priority to customer satisfaction but only from the owner side not all the worker doing that. Structural Capital of SMEs Karya Kulit can be seen from the owner, who is always implement and try ideas and products - new products that are based on market orientation required. Besides, due to the nature of SMEs that family structure resulting data system for easy access to information becomes known to all employees of SMEs. Indirectly SMEs Karya Kulit has been applied intellectual 
capital to give a small boost toward innovation of SMEs Karya Kulit.

We can see for innovation there are 3 factors that don't have significant effect towards innovation like research, strategy and knowledge, these 3 factor shown that all the workers don't have intention to make innovation or new idea, they just works follow the owner's target.

\section{CONCLUSION}

Based on the stages that have been done before in this study, especially in data processing and analysts, we can conclude a few things like the following:

1) Based on the results of the PLS software Tacit Knowledge has no effect on innovation in SMEs Karya Kulit because the workers have not been able to transform the knowledge that the workers have to trigger their innovation in SMEs Karya Kulit happen. Intellectual Capital has an influence on Innovation in SMEs Karya Kulit, but in terms of its application is not directly aware of SMEs Karya Kulit.

2) Factors Tacit Knowledge in SMEs Karya Kulit is Experience, Personal and Community Interaction, this suggests that the knowledge of the workers earned more than the interaction between people at work, this is due to the nature of SMEs that are based on kinship. Intellectual Capital Sources factors that provide the most impact on SMEs Karya Kulit is Relational Capital and Structural Capital, both of these have been carried out by SMEs Leather unwittingly work as do feedback to consumers and also indeed the structure of SMEs that are familial make complex bureaucracy.

\section{SUGGESTION}

Advices that can be given to SMEs Karya Kulit to consider are as follows:

1) Make the workmanship on the condition that the area of personal interaction between workers more frequently.

2) Assignment of the SME employees to conduct information gathering and establish common goals that the workers and the owners know what to improve

3) Encourage all employees to be able to have a target on their self - each instance more rewards when workers perform work in excess of the established standards.

4) Creating a competitive atmosphere by way of compensation for workers who completed the excess of the target so that the ability of workers will increase.

\section{ACKNOWLEDGMENT}

Authors thank Atma Jaya Catholic University of Indonesia for providing the supporting facility in conducting the research. Authors would also like to thank the owner of SMEs Karya Kulit for the opportunity given in conducting in research by providing supportive data so the research could be seamlessly conducted.

\section{REFERENCES}

[1] R. S. Alwis and E. Hartmann, "The use of tacit knowledge within innovative companies: Knowledge management in innovative enterprises," Journal of Knowledge Management, vol. 12, no. 1, pp. 133-147, 2008.

[2] Divianto, "Pengaruh faktor-faktor intelectual capital (human capital, structural capital dan customer capital) terhadap business performance (Survey pada perusahaan swasta di palembang)," Jurnal Ilmiah Orasi Bisnis Edisi ke-IV, pp. 81-99, 2010.

[3] B. Hermana, "Mendorong daya saing di era informasi dan globalisasi: Pemanfaatan modal intelektual dan teknologi informasi sebagai basis inovasi di perusahaan," Universitas Gunadarma, Jakarta, 2005.

[4] K. Auernhammer, M. Neumann, A. Leslie, and F. Lettice, "Creation of innovation by knowledge management: A case study of a learning software organization," Industrial Engineering IAO, Fraunhofer Institute, 2001.

[5] R. S. Alwis, E. Hartmann, and H. G. Gemünden, "The role of tacit knowledge innovation management," presented at the 20th Annual IMP Conference, Copenhagen, 2004.

[6] I. Ghozali, Structural Equation Modeling Metode Alternatif dengan Partial Least Square, Semarang: Universitas Diponegoro, 2006.

[7] G. N. M. Jaya et al., Prosiding Seminar Nasional Matematika dan Pendidikan Matematika, pp. 118-132, 2008.

[8] A. A. Rumanti, "Analysis individual of tacit knowledge toward innovation," in Proc. the 2012 IEEE IEEM, 2012.

[9] W. Yunita, Analisis Korelasi Individual Tacit Knowledge terhadap Inovasi Perusahaan, Universitas Katolik Indonesia Atmajaya, Jakarta, 2010 .

[10] N. Bontis, "Managing organizational knowledge by diagnosing intellectual capital: Framing and advancing the state of the field," International Journal Technology Management, vol. 18, no. 5, pp. 433-455, 1999.

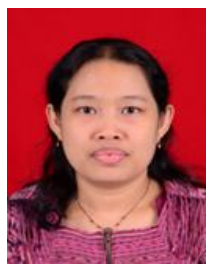

Augustina A. Rumanti was born in Surabaya, on $11^{\text {th }}$ August 1980. She is a lecturer at the Department of Industrial Engineering, Atma Jaya Catholic University in Indonesia and the Department of Industrial Engineering, Telkom University in Indonesia. She received her master degree from Bandung Institute of Technology Indonesia in 2009. Her current interest researches are in the area of organization development, knowledge management and management of technology.

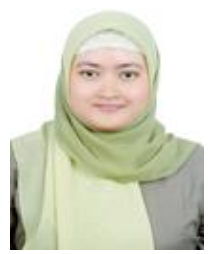

Amelia Kurniawati was born in Bogor, on 9th August 1981. She is a lecturer at the Department of Industria Engineering, Telkom University in Indonesia. She received her master degree from Bandung Institute of Technology Indonesia in 2009. Her current interest researches are in the area of knowledge management and service quality.

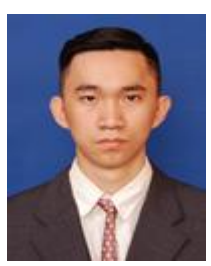

Hendru was born in Jakarta, on 23th October 1993. He majored in industrial engineering at Atma Jaya Catholic University in Indonesia, Jakarta, Indonesia in 2015 and graduated with honors.

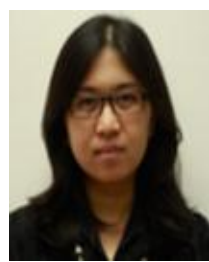

Ceicalia Tesavrita was born in Bandung, on 1st December 1980. She is a lecturer at the Department of Industrial Engineering, Parahyangan Catholic University. She received her master degree from Bandung Institute of Technology Indonesia in 2006. Her current interest researches are in the area of knowledge management and I/O psychology. 